\title{
Inbound Open Innovation Activities in High-Tech SMEs: The Impact on Innovation Performance
}

by Vinit Parida, Mats Westerberg, and Johan Frishammar

Prior studies suggest that open innovation activities positively influence innovation outcomes in large firms. However, few studies have investigated the implications of small and medium-sized enterprises' (SMEs) adoption of open innovation. We address this research gap by investigating the effects of four inbound open innovation activities on innovation performance of SMEs. In doing so, we draw on data from 252 bigh-tech SMEs. Our results reveal that different open innovation activities are beneficial for different innovation outcomes. For instance, technology sourcing is linked to radical innovation performance, whereas technology scouting is linked to incremental innovation performance. These findings hold several important theoretical and practical implications.

\section{Introduction}

Many small and medium-sized enterprises (SMEs) depend on their ability to be innovative for achieving and sustaining competitive advantage. However, the average success rate of innovative efforts tends to be much lower than desirable, mainly due to the high level of risk, complexity, and uncertainty inherent in the innovation process (Cooper, Edgett, and Kleinschmidt 2003; Griffiths-Hemans and Grover 2006; Koufteros, Vonderembse, and Jayaram 2005). In addition, innovative development is usually challenging for SMEs because they are subject to the "liability of smallness," that is, SMEs generally have limited financial resources

Vinit Parida is assistant professor at Entrepreneurship and Innovation, Luleå University of Technology.

Mats Westerberg is associate professor at Entrepreneurship and Innovation, Luleå University of Technology.

Johan Frishammar is professor at Entrepreneurship and Innovation, Luleå University of Technology.

Address correspondence to: Vinit Parida, Department of Business Administration, Technology and Social Science (ETS), Entrepreneurship and Innovation, Luleå University of Technology, SE-971 87, Luleå, Sweden. Tel: +46920 492469. E-mail: vinit.parida@ltu.se. 
(Freel 1999; Grando and Belvedere 2006), often lack a multidisciplinary competence base (Bianchi et al. 2010), and tend to use less structured approaches to innovation (De Toni and Nassimbeni 2003; Vossen 1998). Altogether, these factors may restrict their ability to innovate and achieve competitiveness.

To this background, recent studies in the innovation and technology management domain have proposed several potential benefits of opening up the innovation process. In the literature, this is described as a shift from the traditional or "closed" innovation model, with a main focus on internal research and development (R\&D), toward an "open innovation" approach (Chesbrough 2003; Gassmann 2006; Lichtenthaler 2011). In essence, firms engaging in open innovation actively utilize and exploit inward and outward transfer of knowledge and technologies (Chesbrough, Vanhaverbeke, and West 2006). The notion that firms in general and SMEs in particular may benefit from tapping into external resource bases is not novel (Jarillo 1989), but specific knowledge about the effect of different open innovation activities is limited. Therefore, in this study, we shed light on which open innovation activities SMEs can engage in to spawn their own innovation efforts.

Although most scholars would agree that open innovation activities could be beneficial for SMEs and large firms alike (Chesbrough 2003; Chesbrough, Vanhaverbeke, and West 2006; Lichtenthaler 2008a), to date, the majority of prior research has focused on large or multinational firms (Bianchi et al. 2010; Christensen, Olesen, and Kjær 2005; Lecocq and Demil 2006; Van De Vrande et al. 2009). SMEs are clearly different from larger firms with respect to how they can utilize open innovation activities for innovation outcomes. For example, compared with large firms, SMEs have several inherited limitations, such as lack of resources for R\&D, unstructured innovation processes, and underdeveloped internal capabilities; (Chesbrough and Crowther 2006; Lichtenthaler 2008a; Madrid-Guijarro, Garcia, and Van Auken 2009). On the other hand, SMEs are usually less bureaucratic, more inclined to take risks, possess more specialized knowledge, and are faster in reacting to changing market demands, which all together enables them to be better at gaining from open innovation activities compared with larger firms (Christensen, Olesen, and Kjær 2005; Stam and Elfring 2008; Vossen 1998). Therefore, given the underlining differences between larger and small firms, we argue for specifically focusing on the topic of SMEs and open innovation.

If SMEs become proficient in applying open innovation by collaborating with network partners, they can compensate for the scarcity of internal resources and competences (Christensen, Olesen, and Kjær 2005; Kogut 2000; Lichtenthaler 2008a). Through access to network partners' external resources, SMEs can develop new technological combinations, and thus address or take advantage of a wider range of market opportunities (Baum, Calabrese, and Silverman 2000; Dyer and Singh 1998). Another example is utilizing technology developed elsewhere (Grönlund, Rönnberg-Sjödin, and Frishammar 2010; Lichtenthaler 2008b). This would facilitate SMEs to fill in their internal technological gaps, which are likely to exist due to their focus on specialized technological development. Moreover, as the acquired technology will be tested and proven, it can increase both the speed and quality of innovative activities (Tao and Magnotta 2006; Van De Vrande et al. 2009).

Thus, open innovation activities can hold a wide spectrum of potential opportunities for significantly improving SMEs innovative performance. However, few prior studies have explored this interesting research avenue, and the studies that 
do exist have mainly been case studies and/or conceptual analyses, which make the generalizability of prior findings somewhat limited.

In prior literature, we find examples of open innovation and SMEs studies focusing on the implication of open source strategies (Henkel 2006; Lecocq and Demil 2006), industrial dynamics (Christensen, Olesen, and Kjær 2005), methodologies for technology outlicensing (Bianchi et al. 2010), and effects of intermediate organizations (Lee et al. 2010). To the best of our knowledge, Van De Vrande et al. (2009), Lichtenthaler (2008a), and Laursen and Salter (2006) have published the three prominent studies encompassing a broader set of open innovation activities in SMEs by drawing on larger quantitative data sets. However, one study has excluded small firms (Lichtenthaler 2008a) and another has excluded microfirms (SMEs having less than 10 employees) from the analysis (Van De Vrande et al. 2009), making the results valid only for larger SMEs.

Therefore, even though prior studies have made important contributions to the literature and management practice alike, by addressing open innovation activities in the SME context, there is clearly a need for more quantitative studies that can advance our understanding regarding the effects of open innovation activities in SMEs.

To this background, our study will focus on four distinct inbound open innovation activities, namely technology scouting, horizontal technology collaboration, vertical technology collaboration, and technology sourcing, and investigate their effects on innovation performance in SMEs (Chesbrough, Vanhaverbeke, and West 2006; Lichtenthaler 2008a; Van De Vrande et al. 2009). In line with the study of Laursen and Salter (2006), we use perceptual measures of radical innovation and incremental innovation to measure SMEs innovation performance. In essence, radical innovation represents a firm's ability to develop products that are new to the world or industry, whereas incremental innovation refers to the ability to develop products that are new to the firm. Certain open innovation activities may have stronger positive influence on radical rather than incremental innovative performance and vice versa (Faems, Van Looy, and Debackere 2005; Pittaway et al. 2004; Ragatz, Handfield, and Scannell 1997). Capturing differences related to these two dimensions has not been widely explored (Lane, Koka, and Pathak 2006), and by investigating the two innovation performance dimensions, we were able to provide a more finegrained understating of open innovation activities in SMEs. Therefore, we take these differential effects into account, and commence our arguments about these issues in the sections to come.

Our study contributes to the technology and innovation management literature by providing new insights on how different open innovation activities could enhance innovation performance (Chesbrough 2003; Lichtenthaler 2008a; Van De Vrande et al. 2009). Additionally, we also contribute to the small business management literature by adding to the body on knowledge on how SMEs can benefit from adapting and utilizing open innovation activities. From a managerial perspective, our study provides new insights to owners, managers, and chief executive officers (CEOs) of SMEs about how they can use their limited resources for practicing open innovation to achieve and sustain incremental and/or radical innovation.

The rest of the article is organized as follows. Next, we will present prior research on the topic of open innovation and SMEs, open innovation and innovation performance, and subsequently present eight hypotheses for empirical testing. In the third section, the methods employed in this research are described, including operationalization of con- 
structs and data analysis. We subsequently present the results before we discuss these, and offer conclusions, limitations, and suggestions for future studies in the final section.

\section{Conceptual Background and Literature Review Open innovation and SMEs}

SMEs depend on their ability to be innovative for sustaining competitiveness. However, due to increased competition and rapidly advancing technologies in many industries, SMEs are often forced to develop new products faster and more effectively. This requirement is challenging for SMEs not only because of their limited size, but also because they have less internal resources and a more restricted competence base, which affect their ability to engage in innovative efforts (Cooper, Edgett, and Kleinschmidt 2003; De Toni and Nassimbeni 2003; Pittaway et al. 2004; Powell, Koput, and Smith-Doerr 1996). One way to address these challenging demands is by opening up the innovation process to facilitate increased rents from the interaction with external actors. Prior studies support the idea that utilizing open innovation activities can render SMEs strategic benefits (Chesbrough and Crowther 2006; Chesbrough, Vanhaverbeke, and West 2006; Gassmann 2006; Laursen and Salter 2006; Lee et al. 2010).

Bianchi et al. (2010) make the case for an increasing role of open innovation in SMEs, as they argue that both technology and products are becoming more complex, and it is thus becoming less feasible to engage in product and technology development for a small firm purely by itself. Because the competence and knowledge needed for such development are scattered across firms and institutions (universities), it makes sense to form collaborations with external partners (Frishammar, Lichtenthaler, and Rundquist 2011). In line with the earlier arguments, Van De Vrande et al. (2009) suggest that open innovation activities can provide access to missing knowledge, reduce the costs of development, provide possibilities for risk sharing, and improve the product development process. For example, through the use of an open source development approach, SMEs can gain from the competence of enthusiastic and skilled programmers from around the globe, and compensate for the lack of limited in-house resources (Henkel 2006). Therefore, in accordance with prior literature, we assume that if SMEs are able to integrate and utilize open innovation activities, they can reduce the challenges related to "liability of smallness" and finite resources in the context of innovation (Chesbrough, Vanhaverbeke, and West 2006).

Although the idea that SMEs can reap benefits from open innovation activities is rather intriguing (Bianchi et al. 2010; Chesbrough 2003; Chesbrough, Vanhaverbeke, and West 2006), only a limited number of prior studies have addressed the role of open innovation in SMEs (for an overview and summary, see Table 1). These studies have, indeed, made significant contributions to our understanding of open innovation in the SME context, but they lack generalizable empirical examinations about how different open innovation activities relate to innovation performance. For example, Christensen, Olesen, and Kjær (2005) examined the role of small firms over the technology life cycle and provided a basis for understanding how small firms can benefit from forming collaboration with different partners. Lecocq and Demil (2006) focused on the open innovation strategy of the firm and explained its effects on the industry with respect to new entrants and related aspects. Furthermore, Henkel (2006) provided motives for SMEs to adapt an open source development strategy, and Bianchi et al. (2010) provided a quick and easy-to-use methodology for identification of viable opportunities for out-licensing techno- 


\section{Table 1}

\section{Studies on Open Innovation and Small and Medium-Sized Enterprises (SMEs)}

\begin{tabular}{|c|c|c|c|c|}
\hline Authors & Year & Key Focus & $\begin{array}{c}\text { Type of } \\
\text { Study }\end{array}$ & Key Insights \\
\hline $\begin{array}{l}\text { Christensen, } \\
\text { Olesen, and } \\
\text { Kjaer }\end{array}$ & 2005 & $\begin{array}{l}\text { Innovation } \\
\text { strategy and } \\
\text { management }\end{array}$ & $\begin{array}{l}\text { Qualitative } \\
\text { study }\end{array}$ & $\begin{array}{l}\text { SMEs manage open innovation with respect } \\
\text { to emerging technologies based on their } \\
\text { position within the innovation system and } \\
\text { their stage of maturity of the technology. } \\
\text { For example, SMEs may explore } \\
\text { commercial opportunities with smaller } \\
\text { established players in the early stage of } \\
\text { the technology cycle while they may opt } \\
\text { for collaboration with large incumbents } \\
\text { as technology becomes matured. }\end{array}$ \\
\hline $\begin{array}{l}\text { Lecocq and } \\
\text { Demil }\end{array}$ & 2006 & $\begin{array}{l}\text { Open innovation } \\
\text { strategy }\end{array}$ & $\begin{array}{l}\text { Quantitative } \\
\text { study }\end{array}$ & $\begin{array}{l}\text { The study finds that introduction of open } \\
\text { system strategy leads to an increased } \\
\text { number of new entrants into the industry } \\
\text { as they adopt open systems more readily } \\
\text { than incumbents. Moreover, the diffusion } \\
\text { of open systems into the low-tech } \\
\text { industry leads to decrease in the average } \\
\text { size of the firms in that industry. }\end{array}$ \\
\hline Henkel & 2006 & $\begin{array}{l}\text { Informal } \\
\text { development } \\
\text { collaboration } \\
\text { (Open source } \\
\text { software } \\
\text { development) }\end{array}$ & $\begin{array}{l}\text { Quantitative } \\
\text { study }\end{array}$ & $\begin{array}{l}\text { It was found that smaller firms are likely to } \\
\text { benefit from open source software } \\
\text { development as they usually need } \\
\text { external development support. Also, firms } \\
\text { with long experience of open source } \\
\text { development are more willing to reveal } \\
\text { than protect software codes. }\end{array}$ \\
\hline $\begin{array}{l}\text { Laursen and } \\
\text { Salter }\end{array}$ & 2006 & $\begin{array}{c}\text { Search strategy } \\
\text { for external } \\
\text { knowledge }\end{array}$ & $\begin{array}{l}\text { Quantitative } \\
\text { study }\end{array}$ & $\begin{array}{l}\text { The study suggests that firms that are open } \\
\text { to external sources and search channels } \\
\text { are likely to have a higher level of } \\
\text { innovative performance. However, } \\
\text { oversearch would result in negative effect } \\
\text { on innovative performance. Firms should } \\
\text { be careful with the temptation of } \\
\text { openness and consider the cost of the } \\
\text { search efforts. }\end{array}$ \\
\hline Lichtenthaler & $2008 a$ & $\begin{array}{l}\text { External } \\
\text { technology } \\
\text { acquisition and } \\
\text { external } \\
\text { technology } \\
\text { exploitation }\end{array}$ & $\begin{array}{l}\text { Quantitative } \\
\text { study }\end{array}$ & $\begin{array}{l}\text { The study found that open innovation was } \\
\text { mainly practiced by large firms, as they } \\
\text { are not able to rely only on internal } \\
\text { activities due to the diversification of the } \\
\text { technology knowledge that they use. } \\
\text { They are also likely to have large } \\
\text { resource pool to build up dedicated open } \\
\text { innovation organizational functions. }\end{array}$ \\
\hline $\begin{array}{l}\text { Van de } \\
\text { Vrande, De } \\
\text { Jong, } \\
\text { Vanhaverbeke, } \\
\text { and De } \\
\text { Rochemont }\end{array}$ & 2009 & $\begin{array}{l}\text { Technology } \\
\text { exploitation } \\
\text { and technology } \\
\text { exploration }\end{array}$ & $\begin{array}{l}\text { Quantitative } \\
\text { study }\end{array}$ & $\begin{array}{l}\text { Medium-sized and large firms were found to } \\
\text { embrace open innovation to a larger } \\
\text { extent. However, SMEs were increasingly } \\
\text { opening their innovation process to cope } \\
\text { with lack of internal resources. With } \\
\text { respect to open innovation practices, } \\
\text { utilization of non-R\&D workers' } \\
\text { knowledge was a prominent technology } \\
\text { exploitation activity, and involvement of } \\
\text { customer was a prominent technology } \\
\text { exploitation activity. }\end{array}$ \\
\hline
\end{tabular}




\section{Table 1}

Continued

\begin{tabular}{|c|c|c|c|c|}
\hline $\begin{array}{l}\text { Bianchi, Orto, } \\
\text { Frattini, and } \\
\text { Vercesi }\end{array}$ & 2010 & $\begin{array}{l}\text { Outbound open } \\
\text { innovation } \\
\text { (out-licensing) }\end{array}$ & $\begin{array}{c}\text { Qualitative } \\
\text { study }\end{array}$ & $\begin{array}{l}\text { The study provides an overview on a quick } \\
\text { and easy-to-use methodology for } \\
\text { identification of viable opportunities for } \\
\text { licensing out alternative technology } \\
\text { application. This methodology is based } \\
\text { on the TRIZ instruments, which combine } \\
\text { nonfinancial weights, ranking techniques, } \\
\text { and portfolio management tools. }\end{array}$ \\
\hline $\begin{array}{l}\text { Lee, Park, } \\
\text { Yoon, and } \\
\text { Park }\end{array}$ & 2010 & $\begin{array}{l}\text { Technology } \\
\text { exploitation } \\
\text { and technology } \\
\text { exploration }\end{array}$ & $\begin{array}{l}\text { Quantitative } \\
\text { and } \\
\text { qualitative } \\
\text { studies }\end{array}$ & $\begin{array}{l}\text { The study presents different models of open } \\
\text { innovation within SMEs. In particular, an } \\
\text { intermediate network models is further } \\
\text { investigated, and the important role of } \\
\text { intermediate organization in supporting } \\
\text { SMEs in searching for appropriate } \\
\text { partners and contributing in building trust } \\
\text { between network members is highlighted. }\end{array}$ \\
\hline
\end{tabular}

logy. Finally, Lee et al. (2010) propose different models of open innovation within SMEs and highlight the role of an intermediate organization in supporting SMEs' innovation ambitions.

As mentioned earlier, we have only found three prominent studies that provide empirically generalizable results about the relationship between open innovation and innovation outcomes for SMEs (Laursen and Salter 2006; Lichtenthaler 2008a; Van De Vrande et al. 2009). Laursen and Salter (2006) make a strong case for how open innovation search strategy and search channels influence the innovative performance of SMEs. The other two studies found that large firms embrace and utilize open innovation activities to a larger extent than SMEs (Lichtenthaler 2008a; Van de Vrande et al. 2009). A possible explanation for this outcome could be that CEOs and managers in SMEs have too little knowledge regarding the effects of open innovation, and specifically the potential benefits associated with employing it. In addition, it might be difficult for SMEs to experiment with open innovation activities as the resources they can invest in $R \& D$ activities are limited. Thus, we argue that it is practically and theoretically relevant to investigate how different open innovation activities may influence innovation performance in the context of SMEs.

In the literature, open innovation has been associated with a wide spectrum of activities. Generally, open innovation activities fall into two distinct categories. Inbound open innovation refers to the practice of exploring and integrating external knowledge for technology development and technology exploitation. Outbound open innovation is the practice of exploiting technology capabilities by utilizing not only internal but also external paths of commercialization (Chesbrough 2003; Chesbrough and Crowther 2006). On the one hand, inbound open innovation includes networking or collaborating with other firms or universities for product development, involving customers or end users in product development activities, and licensing-in of intellectual property (IP) from other organizations. On the other hand, outbound open innovation includes the spin-off of new ventures based on prior product or technology development and external involvement in product development and licensingout technologies to other organizations 
(Chesbrough, Vanhaverbeke, and West 2006; Gassmann 2006; Henkel 2006; Lichtenthaler 2008b, 2011; Van De Vrande et al. 2009).

Prior research show that most firms are inclined toward inbound or technology exploration aspects of open innovation (Bianchi et al. 2010; Chesbrough and Crowther 2006; Grönlund, Rönnberg-Sjödin, and Frishammar 2010). A possible reason can be that outbound open innovation activities imposes a higher level of managerial challenge due to the imperfections in the markets for technologies (Lichtenthaler and Ernst 2007) and lack of systematic internal process to drive such initiatives (Lichtenthaler, Lichtenthaler, and Frishammar 2009). Though we do realize that much more research is needed on the outbound dimension of open innovation in SMEs, the current study focuses on the inbound dimension. Our reason for doing so is that many SMEs still struggle with inbound activities due to strategic challenges, such as technology pricing, IP disclosure, and partner negotiations. Thus, by investigating this dimension, we also assure a sufficient sample size of SMEs with reasonable levels of experience in these activities. Specifically, we study four inbound open innovation activities: technology scouting, vertical technology collaboration, horizontal technology collaboration, and technology sourcing, and their effect on radical and incremental innovation performance.

\section{Innovation performance outcomes of open innovation}

The seminal book by Chesbrough (2003) makes a strong case for integration and utilization of open innovation activities as a way to drive innovation outcomes and sustain competitiveness in dynamic environments. However, due to a lack of quantitative studies on this topic, the proposed effects of open innovation have not been sufficiently investi- gated in the context of SMEs (Lichtenthaler 2008a; Van De Vrande et al. 2009). Chesbrough and Crowther (2006) propose growth and revenue as the main motive for conducting inbound open innovation, whereas Lichtenthaler, Lichtenthaler, and Frishammar (2009) support the use of more nonmonetary outcomes, such as increased customer satisfaction or the acquisition of new knowledge. However, in line with Laursen and Salter (2006), we propose that the relationship between open innovation activities and innovation performance is central.

Although we realize that firms engage in open innovation activities for different reasons, we empirically study the link between the inbound open innovation activities and innovation performance. Innovative performance may vary along a newness continuum, ranging from radical to incremental (Ettlie, Bridges, and O'Keefe 1984; Laursen and Salter 2006; Sher and Yang 2005). Radical innovations are ground-breaking development that requires significant resources to materialize. Many times, such innovation has longer time lags to profitability compared with incremental innovations (Chaney, Devinney, and Winer 1991; Veryzer 1998). Although radical innovation could enable existing SMEs to establish a dominant position in a market niche and provide new firms with an opportunity to gain a dominant position in the market, it could also expose firms to an increased level of risk.

Incremental innovation, on the other hand, are development and improvements of products and services that do not fit into the first category. It can range from development of new products (that are known to the market) to minor improvements in existing products and services (Atuahene-Gima 2005; Laursen and Salter 2006). The intention of incremental innovation is to use the insights from customers or others to develop better solutions that are attractive and 
would add to the profits from the existing products (Pavitt 1998; Xin, Yeung, and Cheng 2008). In theory, firms adapting open innovation activities should be able to support both innovation outcomes. However, it appears that certain open innovation activities might be more favorable for incremental innovation, whereas others are better settled to spawn radical innovation.

According to Veryzer (1998), the methods and approaches employed by firms to develop radical or discontinuous innovations are largely different from incremental innovation. The reason for this is rooted in the genetics of these two innovation types which often differentiate on the degree of technological uncertainty, development time, and complexity of the development processes. Several prior studies exemplify these different outcomes. For example, according to Faems, Van Looy, and Debackere (2005), collaboration with partners from the value chain (customers and suppliers) provides a strong base for incremental development of existing products and services, whereas collaboration with academic institutions increase the ability of firms to drive radical development due to access to new technologies. Similarly, Miotti and Sachwald (2003) support the view that opening the innovation process to inputs from research institutions could enable firms to conduct research at the technological frontier and develop patents for new-to-the-world products. Moreover, forming innovation cooperation with competitors may also have a more positive effect on the incremental dimension of innovation performance (Belderbos, Carree, and Lokshin 2004). To conclude, we propose that two types of innovation performance will be related to the open innovation activities in different ways.

\section{Hypotheses Development}

Technology scouting represents an internal search or scanning function related to systematically assessing and observing technology trends in order to detect opportunities and encounter threats in a timely manner (Bianchi et al. 2010; Katila 2002; Laursen and Salter 2006; Lichtenthaler 2007). The purpose of technology scouting is not to gather large sets of detailed information, but rather to create insights or awareness regarding significant patterns of change in the external environment (Van Wyk 1997). However, due to the complexity and dynamism of technological developments, it is challenging for most firms to generate an appropriate information base about the technological trends (Lichtenthaler 2003). Still, the scouting component has been highlighted in prior seminar work on absorptive capacity (Cohen and Levinthal 1990), and suggested to be a key cornerstone for the theoretical framework of open innovation (Lichtenthaler and Lichtenthaler 2010).

A recent study by Lichtenthaler, Lichtenthaler, and Frishammar (2009) shows the importance of analyzing a firm's technological environment to gather ideas, information, and knowledge useful to support its internal innovation process, although this study was performed outside the SME context. Thus, firms with advanced scouting mechanisms would be able to identify opportunity gaps in the market and undertake sound decisions regarding which innovative products ideas to develop. Moreover, by introducing such innovative products before their competitors, they would be able to realize a "first mover advantage" (Cohen and Levinthal 1990). This function can become particularly important for SMEs with limited internal resources and by having a clear direction for innovative product development so that they can utilize their resources effectively.

However, technology scouting can have negative effects on innovation performance of SMEs as it can result in the identification of too many potential ideas (Frishammar and Hörte 2005). In such 
cases, SMEs might struggle to allocate sufficient internal resources to manage and prioritize ideas. In addition, SMEs may also lack the ability to balance "attention allocation," leading to negative consequences (Koput 1997). However, as suggested by Laursen and Salter (2006, p. 146), "firms who are more open to external sources or search channels are more likely to have higher level of innovative performance. Openness to external sources allows firms to draw in ideas from outside to deepen the pool of technological opportunities available to them." Therefore, we propose that technology scouting represents an important inbound open innovation activity, which has the potential to drive innovation performance of SMEs.

\section{H1a: Technology scouting is positively related to innovation performance in SMEs.}

Even if technology scouting seems beneficial for radical innovation performance as a way to acquire novel ideas that can lead to development of breakthrough products, we argue that technology scouting is more likely to enhance incremental innovation as it may help the focal firm to hone its present innovation process. This is because in comparison to larger firms, SMEs possess specialized and deep knowledge (Gans and Stern 2003; Giarratana 2004). Moreover, SMEs usually have a focused business portfolio, which represents their strength (Vossen 1998) but also limits their ability to scan and search for technological opportunities outside their own industry (Bianchi et al. 2010; Zahra and George 2002). Thus, they are normally better at conducting local search or scouting activities than searching for diverse and novel knowledge. This is due to the fact that firms largely depend on preexisting knowledge bases for scouting activities which, in the case of SMEs, often are limited. SMEs can overcome this limitation by employing a broader and deeper search or scanning strategy of their external environment (Laursen and Salter 2006), but this is challenged by resource constrains. Considerable resources may be needed in terms of recruiting specialized employees and develop dedicated technology scouting units, which are costly and seldom feasible for SMEs (Rothwell and Dodgson 1991). Thus, we propose that SMEs normally would prefer to scout within their known industrial boundaries, which makes them more likely to achieve incremental innovation as compared with radical innovation. Therefore, we suggest the following hypothesis:

\section{H1b: Technology scouting is more strongly related to incremental as opposed to radical innovation perfor- mance in SMEs.}

Vertical technology collaboration captures collaborative relationships with customers (i.e., vertical downstream collaboration) or supplier (i.e., vertical upstream collaboration) (Baum, Calabrese, and Silverman 2000). However, in the context of open innovation, multiple studies regard vertical technology collaboration with present customers, potential customers, and end users as one of the key alternatives for an improved internal innovation process (Chesbrough, Vanhaverbeke, and West 2006; Gassmann 2006; Henkel 2006; Von Hippel 2005). Thus, in this study, we specifically focus on the vertical downstream technology collaboration.

According to Gemünden, Heydebreck, and Herden (1992), approximately 75 percent of firms are integrating customers into their innovation process. However, the intensity of collaboration may differ widely. In the context of open innovation, vertical technology collaboration could represent a more active involvement of customers and users as they become key stakeholders in the development process, and in certain 
cases, codevelop technologies together (Chesbrough 2003; Enkel, Kausch, and Gassmann 2005). SMEs usually consider collaboration with larger customer firms as they hold strong resources to convert ideas and inventions into commercially viable innovative products. Therefore, it is not surprising that SMEs in several industries, such as in the biotech industry, have long been associated with initiating collaboration joint projects where they provide the specialized knowledge for development of the innovative product, whereas large firms provide the needed infrastructure and resources for manufacturing, marketing, and commercialization (Kleinknecht and Reijnen 1992; Oliver 2001). SMEs can also struggle to tap into their present and potential customers need and requirements. This challenge is increasingly becoming obsolete due to the increased use of information and communication technology, which facilitates SMEs to access customer insights in a cost-effective manner (Dahan and Hauser 2002).

According to Dyer and Singh (1998), vertical technology collaboration could increase the ability of a firm to innovate and create value because it becomes more aware of customers' needs and expectations. Moreover, involving customers in the early phases of innovation significantly reduces risks in development and improve the likelihood of innovation success (Ragatz, Handfield, and Petersen 2002). Customer collaboration in the innovation process could also have a positive influence on idea generation, product concept development, prototype testing, and market launch, leading to innovation success (Gruner and Homburg 2000).

Another aspect of vertical technology collaboration concerns collaborating with qualified customers, that is, lead users. This group of users are usually forerunners regarding the products they use, and could thus provide unique insights critical to the internal innovation process (Von Hippel 2005). In addition, there are cases when users have developed their own products that producers have later imitated successfully. Thus, assuring customer and user inputs helps firms produce customized and commercially viable products. Firms might also codevelop products with certain customers and users such as in the case of open source software development (Henkel 2006). Still, there are drawbacks with vertical technology collaboration too. For example, firms that follow their customers too closely may loose their competitive advantage (Christensen and Bower 1996). Still, it appears that the gains outweigh the drawbacks, and we propose the following hypothesis.

\section{H2a: Vertical technology collaboration is positively associated to innovation performance in SMEs.}

With respect to vertical technology collaboration, perhaps most clearly, lead users may be critical to achieve radical innovation by informing the firm about entirely new product and service options (Von Hippel 2005), but customer involvement generally appears linked to incremental innovation. For example, using customer feedback and customer interaction for improving the current products and services (Belderbos, Carree, and Lokshin 2004; Christensen and Bower 1996; Enkel, Perez-Freije, and Gassmann 2005; Faems, Van Looy, and Debackere 2005). This could be explained by understanding the risks associated with vertical technology collaboration. According to Enkel, Kausch, and Gassmann (2005), quite often, parts of customers' insights are lost in the integration process, which means that a firm may not actually understand those needs correctly, blindly depending on customers' demands, personality, and views may also limit the level of innovativeness, and end up developing products for a niche market. Moreover, as custom- 
ers who are involved in the innovation process largely rely on their experience, they could only be able to reflect upon how to improve the products they are familiar with, rather than trying to provide inputs for developing radical products (Von Hippel 2005). Therefore, we suggest the following hypothesis:

\section{H2b: Vertical technology collaboration is} more strongly related to incremental as opposed to radical innovation performance in SMEs.

Horizontal technology collaboration refers to collaborating with partners that are not part of the value chain of a particular SME. These linkages could include partners from similar or other industries, such as competitors or noncompetitors, and they can be large firms or other SMEs. Forming R\&D collaboration with noncompetitor firms is typically easier due to the possibility of developing win-win collaboration as both actors could see the advantage of combing resources and competences to develop innovative products (Pittaway et al. 2004). SMEs may find it attractive to initiate a risk and revenue-sharing agreement with partners across industries as the cost of innovative development usually tends to be prohibitively high for SMEs compared with their larger counterparts that can sustain large R\&D units (Baum, Calabrese, and Silverman 2000). In comparison, technological collaboration with competing firms can be complex and risky, but if collaborating firms can identify common goals, the likelihood of leveraging technological development through external support can increase significantly (Lee et al. 2010; Lichtenthaler 2005). Moreover, when a competing partner firm is from the same or similar industry, it could facilitate the access to and interpretation of uncodified knowledge leading to innovation success (Liebeskind et al. 1996).
In addition, due to the ever-increasing complex nature of technological products, SMEs may find it overwhelming to handle R\&D activities by themselves. Thus, forming collaboration with competitors and/or noncompeting firms to acquire and leverage from their technology capabilities could be a beneficial strategy (Hagedoorn, Roijakkersand, and Van Kranenburg 2006). SMEs could benefit from exploring innovative development and commercialization opportunities with other small established firms as they can jointly enter new markets and substantially improve their chances against larger competitors (Christensen, Olesen, and Kjær 2005; Lee et al. 2010). In addition, horizontal technological collaboration can have a "spillover effect" for SMEs as they may benefit from the experiences of their partner firms, which could lead to learning effects for future innovative developments (Argote and Ingram 2000).

Although compelling, the open innovation activity of horizontal technological collaboration can also have negative effects for SMEs' innovative performance. For example, forming strategic alliances with partners outside the value chain could result in higher transaction costs as collaborating partners may freeride by restricting contribution to the collaboration or act opportunistically (Bessant, Kaplinsky, and Lamming 2003; Bradley, Meyer, and Gao 2006; Hamel and Prahalad 1994). In either case, SMEs could suffer major losses due to the lack of resources and negotiation power to meet such unpredictable partner behavior. However, in light of the significant potential benefits associated with the inbound open innovation activity of horizontal technology collaboration, we hypothesize a positive effect on innovation performance of SMEs.

H3a: Horizontal technology collaboration is positively associated to innovation performance in SMEs. 
Technology collaboration outside the value chain can be useful for incremental innovation performance as SMEs can benefit from the expertise and experience of collaborating firms to make improvements to their products. However, as technology collaboration involves greater risks, it can be expected that SMEs will engage in such collaboration when they foresee a clear potential for more radical development. Moreover, as SMEs expand collaboration with partners across industry, they develop nonredundant network relationships, which can have a positive influence on SMEs ability to access more diverse information and resources (Burt 2004). Through such collaborations, SMEs can create new and highly innovative technological combinations (Katila 2002; Katila and Ahuja 2002), leading to positively influencing the radical dimension of innovation performance. This also links to a discussion in social network research, which suggests that radical innovation is much more contingent on "weak ties," as through such links, SMEs can gain access to new and distant knowledge and information (Burt 2004; Kim and Aldrich 2005).

SMEs may also utilize horizontal collaborations for ensuring successful commercialization and marketing of radical innovations in new markets (Pittaway et al. 2004). In addition, the competitor and noncompetitor partners may provide the legitimacy and recognition to SMEs for enhancing radical innovation performance. Thus, we propose that horizontal technology collaboration with different actors is an important open innovation activity for SMEs and would be strongly linked to radical innovation performance.

H3b: Horizontal technology collaboration is more strongly related to radical as opposed to incremental innovation performance in SMEs.
Technology sourcing represents an open innovation activity for buying or using external technology through IP agreements. Many SMEs can benefit from this activity because they are faced with the challenge of shortened product life cycles, rapid changes in technologies, and shortage of capital. According to Van De Vrande et al. (2009), SMEs can address these challenges by licensing in technology from external sources as it can fuel and accelerate their internal innovation process. Chesbrough, Vanhaverbeke, and West (2006) suggest that such inward technology sourcing is practically important for firms operating in an R\&D-intensive (high-tech) industry as there is usually high demand on them to be innovative. Although external acquisition of technological know-how could be a strategic innovation activity, firms may struggle with this transfer due to the high level of tacit knowledge associated with the technologies (Vanhaverbeke, Duysters, and Noorderhaven 2002). Nevertheless, many SMEs aim to capitalize on external knowledge by technology sourcing from different actors, such as other firms, research institutions, and universities for three reasons. First, focusing on internal $R \& D$ requires large investments of capital, time, and personnel. These investment costs could be significantly reduced when SMEs opt for technology sourcing as they would focus only on search, evaluation, adaptation, and royalty costs (Atuahene-Gima 1993). Second, if firms focus on internal innovation processes, they would limit their ability to be flexible to the emerging opportunities as a development cycle requires long lead times (Håkansson and Laage-Hellman 1984). Thus, through technology sourcing, SMEs can advance their internal innovation process as they can integrate almost-ready technologies from external sources and use it to address the emerging gaps in the market (Anokhin, Wincent, and Frishammar 2011; Chesbrough, Vanhaverbeke, and 
West 2006). According to Teece (1989, p. 38), technology sourcing and similar activities enable firms to "preserve an open window on science and technology and to alert to changing opportunities and threats." Finally, technology sourcing can improve innovation performance because it allows SMEs to develop complex product through integration of tested and proven technologies (Atuahene-Gima 1992; Tao and Magnotta 2006). However, there are clear drawbacks to extensive sourcing as well. First, too much sourcing may lead to limited internal development of critical technological knowledge, and thus reduced possibilities to develop technological core competencies (Lichtenthaler 2010). In addition, SMEs may experience problems with the "not invented here" syndrome (Katz and Allen 1982), which could make it difficult to exploit technology developed elsewhere. Again, however, the potential upsides seem to outweigh the risks, and we propose the following hypothesis.

\section{H4a: Technology scouring is positively associated with innovation perfor- mance in SMEs.}

As most SMEs operate in a niche market and offer their product to specific customer segments, they are usually well informed about customers' needs and requirements (Pittaway et al. 2004). Thus, by combining their market knowledge with technology scouring activities, they can make incremental innovation and continue to generate revenues. Such initiatives would require low investment on the part of the SMEs and still make them innovative in their current market (Atuahene-Gima 1993). However, we argue that inward technology scouring may have a stronger role for radical innovation. As development of new-to-theworld type of innovations required SMEs to access and gain from diverse knowledge bases and competences, they can fill these gaps through licensing in technologies from external actors. The role of universities and research institutions could be pivotal because several innovations would not have been achieved without their influence (Fontana, Geuna, and Matt 2006). University and research institutions are well known sources of offering such specialized technologies and knowledge, which SMEs can benefit from and use as a base for the development of radical innovation (Mohnen and Hoareau 2003). Moreover, as the technologies are mature and pretested, the risk of product failure is reduced even when developing radically new products. Therefore, we propose the following hypothesis.

H4b: Technology sourcing is more strongly related to radical as opposed to incremental innovation performance in SMEs.

The eight hypotheses discussed in this section form the basis of Figure 1 . The underlying logic in this model is that all four inbound open innovation activities positively influence both types of innovation performance but to different degrees. A thick arrow indicates a strong(er) relationship, whereas a thin arrow indicates a weak(er) relationship.

\section{Methods}

\section{Sample and data collection}

To test the hypotheses, a survey targeting technology-based SMEs in the information and technology (IT) sector in Sweden was conducted between March and May of 2009. Technology-based SMEs were selected because these firms operate in a dynamic environment where innovative abilities are necessary for growth and survival. Moreover, we limited the survey to a single industry to avoid unnecessary "noise" due to industry factors (Westerberg, Singh, and Häckner 1997). 


\section{Figure 1}

\section{Illustration of the Proposed Hypotheses}

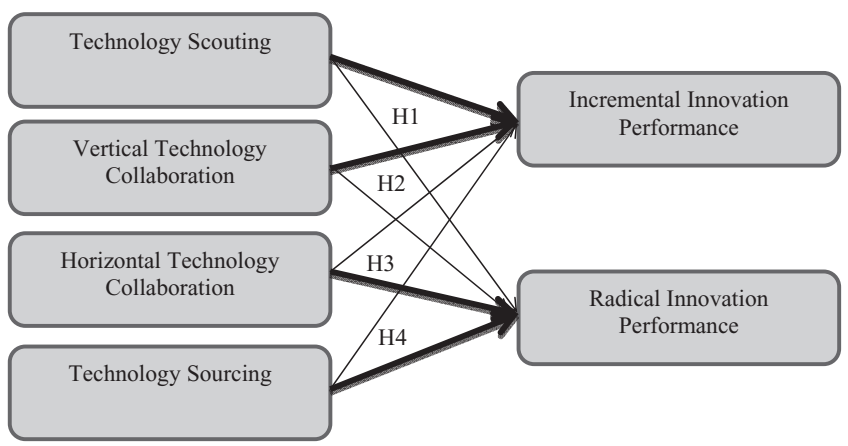

A Swedish business database (Affärsdata) containing all active firms in Sweden was used to obtain the sample, where we included firms classified according to SIC 62010 and 62020, representing firms involved with consultancy-related computer systems or computer software production. ${ }^{1} \mathrm{We}$ employed two sampling constraints. First, the targeted firms should be SMEs according to the European Union definition, and thus have fewer than 250 employees. Second, the firms should have a turnover of at least USD $150,000^{2}$ to ensure an active firm. As the vast majority of firms only have a few employees, we sample only a small portion of firms up to seven employees (300 out of a total 1,500). For firms with eight employees and up, all firms were included in the sampling frame. This means that the results mainly reflect firms with more than eight employees. This resulted in the identification of 1,500 firms, which was considered as the total population for the survey.
A self-administrated questionnaire was subsequently developed. To enhance external validity, the questionnaire was checked for any problems or irregularities, and was pretested on five CEOs of SMEs and five academics. The survey was addressed to the CEO of each SME, with a cover letter explaining the purpose of the study. After a reminder, a total of 252 usable and complete questionnaires were received, a response rate of 16 percent. As the study targeted the CEOs of SMEs, it is expected to be quite low (Baruch 1999; Baruch and Holtom 2008), and the study's response rate may have been exacerbated by the negative economic climate and an increased research focus on SMEs, especially in the information and communications technology sector. Still, a nonresponse analysis including the variables of age (year of establishment), size (number of employees), profitability, sales, sales per employees, and solidity (the degree of internally funded capital) showed no significant differences between respondents and nonrespondents.

\footnotetext{
${ }^{1}$ Since the Swedish industry code system is not fully compatible with US SIC, it is not possible to find a perfect matching. However, the sampled firms are all part of industries with the US SIC starting with 737.

${ }^{2}$ Based on a currency rate where 1 USD $=6.67$ SEK.
} 


\section{Measures}

Based on and inspired by the study by Van De Vrande et al. (2009), we measured four inbound open innovation activities. First, technology scouting (three items) refers to the process of observing technology trends, viewing external sources for ideas and knowledge, and collecting information about the technological environment ( $\alpha=0.82$ ). Second, borizontal technology collaboration refers to opening the product development process for extending the collaboration with actors or partners outside the value chain of an SME. Three items were used for this construct, all of which address the practice of cooperating with other firms (competitors and/or noncompetitors), networking to exchange experiences/ knowledge with partners, and benefiting from important inputs from partners $(\alpha=0.83)$. Third, vertical technology collaboration (three items) refers to the process of integrating inputs from present and potential customers, and end users $(\alpha=0.82)$. Finally, technology sourcing (two items) is the process of accessing, using, and buying technologies from other firms and institutions for driving the product development process. In the open innovation context, it can also be regarded as the process of inward IP licensing of technologies $(\alpha=0.67)$. For details on the factor loadings, see appendix $\mathrm{A}$.

Innovative performance was the dependent variable, which we measured by employing the scales developed by Laursen and Salter (2006), and AtuaheneGima (2005). Radical innovation indicated the ability of the firms to produce innovations that were "new to the world." Incremental innovation is the firms' ability to produce product innovations that were "new to the firm." Based on these dimensions, the respondents were asked to report the frequency of such innovations in the last three years and the amount of such innovations launched in comparison to their competitors in the last three years (two items). The innovative performance dimension of radical innovation $(\alpha=0.93)$ and incremental innovation $(\alpha=0.85)$ scales both showed acceptable reliability. The two dimensions were considered important to capture the differences in terms of innovative outcomes, which have been lacking in many prior studies (Lane, Koka, and Pathak 2006).

Several control variables were used. Firm age was calculated by the log of the number of years since establishment, and was included because younger firms tend to be more innovative even when they possess less-developed capabilities and resources (Huergo and Jaumandreu 2004). Another control variable was firm size, which was calculated by taking the $\log$ of the total number of employees. Size was considered important because larger firms might be able to innovate faster than small firms due to their possession of greater resources (Dewar and Dutton 1986). Possible influences of the environment were based on Miller and Friesen (1982) and capture hostility (four items), heterogeneity (three items), product dynamism (two items), and market dynamism (two items). Finally, we also controlled for the degree of internationalization (percentage of sales on international market) as SMEs that are more internationally oriented tend to be more innovative (Frishammar and Andersson 2009).

\section{Analytical procedures}

We used conventional hierarchical regression analysis to test the relationships between the four inbound open innovation activities and the two dimensions of innovative performance. Collinearity tests were performed to analyze to what extent each of the individual construct scores were dependent on the other construct scores. All variance inflation factor values were less than 1.7, which suggested multicollinearity was 
not a major problem (Hair et al. 2006). To test for common method bias, we followed the guidelines set by Podsakoff et al. (2003) and Podsakoff and Organ (1986). We thus used a Harmon factor analysis by entering all the self-reported variables used in the analysis into a factor analysis. Four factors with eigenvalues $>1.0$ were extracted, accounting for 60.59 percent of the variance. The first factor accounted for 22.86 percent of the variance. Because more than one factor was identified, and individual factors accounted for the majority of the variance explained, common method bias was not judged as a major issue, although we cannot fully rule out the existence of a common method bias.

\section{Results}

The correlations and descriptive statistics are listed in Table 2, whereas Table 3 displays the results of the regression analysis. In short, all four a-hypotheses received support as all inbound open innovation activities have a positive and significant effect on either incremental or radical innovation performance, whereas only two of the b-hypotheses received support.

Turning to the individual hypotheses, $\mathrm{H} 1 \mathrm{a}$ receives strong support as technology scanning is significantly related to both incremental $(\beta=0.17, p<.01)$ and radical $(\beta=0.11, \quad p<.10)$ innovation. $\mathrm{H} 1 \mathrm{~b}$ is weakly supported as the coefficient for incremental is higher than that of radical innovation. However, the coefficients are not significantly different from each other. $\mathrm{H} 2 \mathrm{a}$ received mixed support as vertical technology collaboration is significantly related to radical ( $\beta=0.15, p<.05)$ but not to incremental $(\beta=0.08$, n.s.) innovation. $\mathrm{H} 2 \mathrm{~b}$ was rejected as the only significant result is found for the link to radical innovation. Similar to $\mathrm{H} 2 \mathrm{a}, \mathrm{H} 3 \mathrm{a}$ received mixed support, where horizontal technology collaboration is significantly linked to incremental $(\beta=0.14, p<.05)$ but not to radical $(\beta=0.00$, n.s. $)$ innovation. $\mathrm{H} 3 \mathrm{~b}$ was rejected as the significant result is evidenced for incremental innovation. Finally, H4 received strong support for both the $\mathrm{a}$ and $\mathrm{b}$ hypotheses. For $\mathrm{H} 4 \mathrm{a}$, technology sourcing was significantly linked to both incremental $(\beta=0.16$, $p<.05)$ and radical $(\beta=0.37, p<.01)$ innovation. For $\mathrm{H} 4 \mathrm{~b}$, the strongest effect was found for radical innovation, and it is also significantly stronger than the effect on incremental innovation.

\section{Discussion and Conclusions}

In this study, we explored the theoretical concept of inbound open innovation in the SME context. More specifically, we have empirically investigated the effect of four inbound open innovation activities on innovation performance of SMEs. Our empirical results have provided strong support for the importance of open innovation in the context of SMEs. Despite actively addressing these inbound activities, many SMEs still experience major difficulties in performing open innovation activities, which constitutes key managerial challenges for SMEs opting for a more open approach to innovation. The positive effects of the inbound activities, thus, highlight the link between such activities and innovative performance in the context of increasingly open innovation processes among SMEs. Altogether, these results deepen our understanding of previously reported discrepancies between successful and less successful SMEs involved with open innovation (Bianchi et al. 2010; Henkel 2006; Laursen and Salter 2006; Lichtenthaler 2008a; Van De Vrande et al. 2009). The findings are particularly relevant in light of a growing interest of both academics and managers of SMEs to understand the enablers of and barriers to successful inbound open innovation activities. 


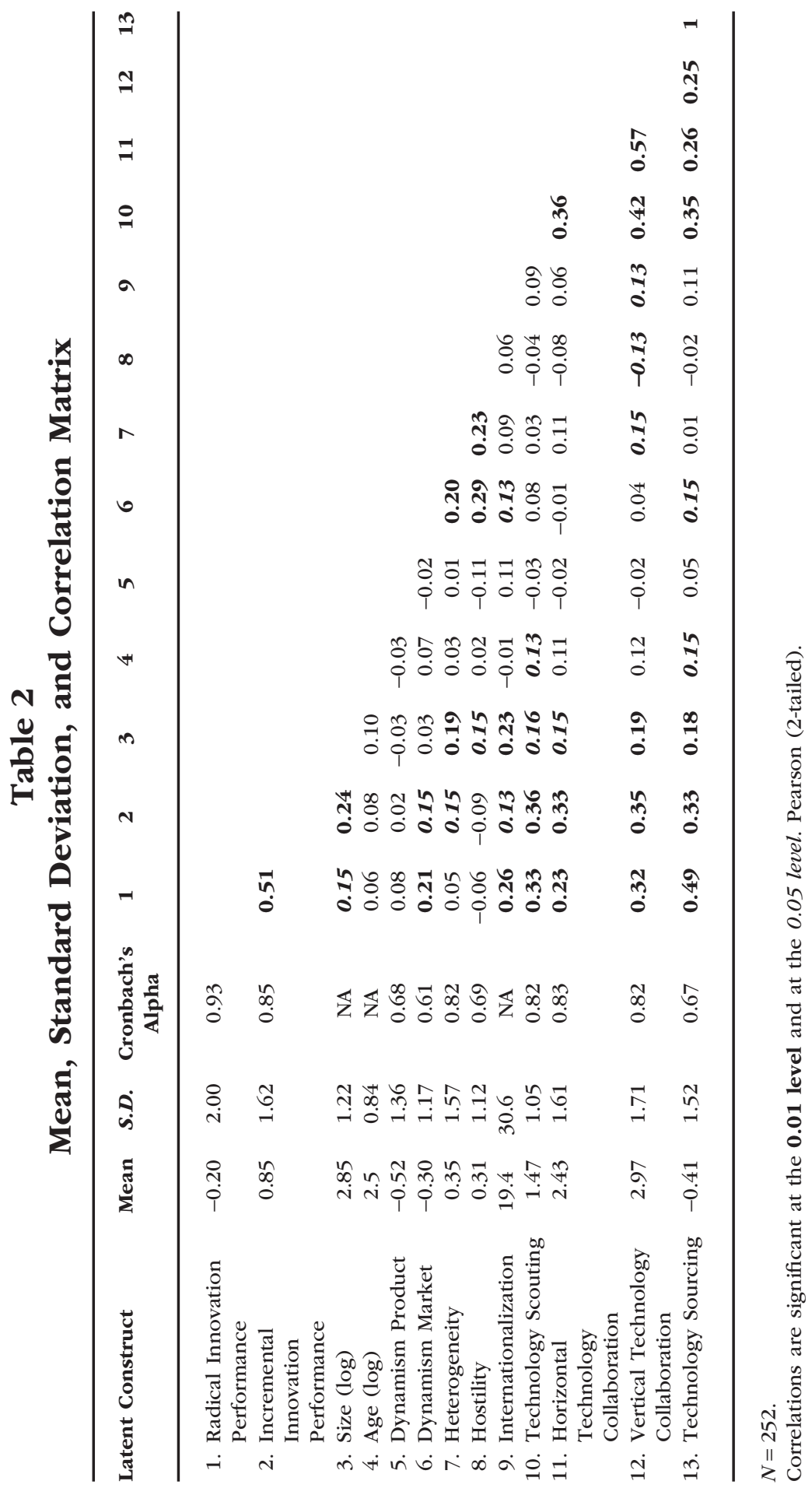


Table 3

Regression Analysis for Open Innovation Practices in

Small and Medium-Sized Enterprises

Radical Innovation
Performance New
to the World $\begin{gathered}\text { Performance New } \\ \text { to the Firm }\end{gathered}$

Size $(\log )$

0.110* 0.006

$0.228^{* * * *} \quad 0.143^{* * *}$

Age (log)

$0.040-0.033$

0.047

$-0.013$

Dynamism Product

0.045

0.041

$-0.005$

0.004

Dynamism Market

$0.224^{* * * *}$

$0.144^{* * *}$

$0.172^{* * * *}$

$0.126^{* * *}$

Heterogeneity

Hostility

Internationalization

0.000

$-0.005$

$0.113^{*}$

0.092

$-0.1542$

$-0.076$

$0.217^{* * * *}$

$0.173^{* * * * *}$

$-0.211$

$-0.140$

Technology Scouting

Horizontal Technology

$0.114^{*}$

0.059

0.027

$-0.002$

$0.173^{\text {***** }}$

$0.138^{* * *}$

Collaboration

Vertical Technology Collaboration

$0.152^{* * *}$

0.088

Technology Sourcing

$F$-ratio

$R^{2}$

$R^{2}(\operatorname{adj})$

Sign

$R^{2}$ Change

$0.375^{* * * * *}$

$0.158^{* *}$

$F$ ( $R^{2}$ Change)

Sign ( $R^{2}$ Change)

$\begin{array}{cc}5.54 & 12.0 \\ 0.137 & 0.355 \\ 0.112 & 0.325 \\ <0.001 & <0.001 \\ & 0.218 \\ & 20.3 \\ & <0.001\end{array}$

5.22

8.29

0.13

0.274

0.105

0.241

$<0.001$

$<0.001$

0.145

12.0

$<0.001$

$N=252 . * p<.10 ; * * p<.05 ; * * * p<.01$.

Regression coefficients shown are beta coefficients.

\section{Theoretical implications}

The empirical findings have highlighted that the adoption and utilization of open innovation activities can positively influence innovative performance of SMEs. This notion is strongly supported as all four inbound activities are linked positively to at least one aspect of innovation performance and there is no negative links present. The few prior studies on the topic agree on this importance of SMEs opening their innovation process to external influences (Bianchi et al. 2010; Henkel 2006; Lee et al. 2010), although there has been a lack of quantitative empirical support prior to our study. Moreover, the survey studies by Van De Vrande et al. (2009) and Lichtenthaler (2008a) have found that open innovation is mainly driven by larger companies than SMEs due to the associated challenges. We build on their findings and argue that if SMEs can perform technology scouting, vertical and horizontal technology collaboration, as well as technology sourcing, they can 
partly overcome their liability of smallness and drive their innovation performance better than if all innovative activities are done in-house.

In general, most of the research on open innovation in SMEs have been conceptual or qualitative, which has resulted in a lack of understanding of more generalized findings and effects. We close this gap in the technology and innovation management literature by not only identifying innovation performance as a suitable dependent variable for future studies on the topic of open innovation but also by distinguishing radical from incremental dimensions (Atuahene-Gima 2005; Laursen and Salter 2006). Our results provide credence for this as we find that inbound open innovation activities have different influence patterns on the two aspects of innovation performance. This could be of specific importance for SMEs because the contingency for both dimensions of innovation performance are significantly varied based on the level of risk, investment, and development time (Chaney, Devinney, and Winer 1991; Ettlie, Bridges, and O'Keefe 1984; Sher and Yang 2005).

For example, our analysis shows a rather strong support for how technology scouting and technology sourcing affect the different aspects of innovation performance. Scanning tends to be more important for incremental innovation, whereas sourcing is more important for radical innovation, which is fully in line with the stated hypotheses. Moreover, it is important to note that technology scouting and sourcing are two inbound open innovation activities that are linked to both incremental and radical innovation performance. Therefore, and in line with the prior studies in technology and innovation management (Bianchi et al. 2010; Chesbrough, Vanhaverbeke, and West 2006; Van De Vrande et al. 2009), we support the view that an emphasis on these activities by SMEs would fuel their innovation process.
Regarding the technology collaboration hypotheses, the pattern we anticipated is completely reversed as vertical technology collaboration was found to have an influence on radical innovation performance and horizontal technology collaboration instead of incremental innovation performance. This counterintuitive result may reside in the particular circumstances of the empirical domain of our study. Several studies have held the view that vertical (customer and end user) collaboration mainly drives incremental innovation (Belderbos, Carree, and Lokshin 2004; Faems, Van Looy, and Debackere 2005; Pittaway et al. 2004), but in the high technology-based industry, customers tend to be larger firms (e.g., IBM and Siemens) that are more aware and informed about their current and future requirements. Thus, they may actually drive radical development in technologically specialized SMEs to meet their emerging needs. Moreover, recent studies in the field of open source can also provide some explanation as in that context of end users and lead users driving radical development (Henkel 2006). In line with the earlier argument, Von Hippel and Katz (2002) propose that within the high-tech industry, several firms are using an entirely new approach (user innovation) to product development, where users are given the tools to be innovative. Thus, SMEs in high-tech industries may actually gain inputs from customers and end users about developing new-to-the-world innovations, compared with developing significant improvement to existing products. Thus, contrary to the view within the technology and innovation management literature, our study provides an alternative explanation on how SMEs can benefit from vertical technology collaboration.

Contrary to our hypothesis, horizontal technology collaboration was found to have a positive influence on incremental innovation performance. SMEs in the technology sector (e.g., biotech) form 
horizontal collaborations with competitor and noncompetitor firms for sharing risks and cost of development (Kleinknecht and Reijnen 1992; Oliver 2001). However, such collaborations are known to suffer from high transaction costs and opportunistic behavior on the part of large firms (Christensen, Olesen, and Kjær 2005). Therefore, it can be expected that SMEs may opt for a more conservative collaboration strategy, where they focus on using horizontal collaboration for market diversification or creating new to industry product bundling.

In conclusion, SMEs can greatly benefit from these key inbound open innovation activities to advance their innovation performance. However, when making the choice as to which activity they should invest their limited resources, the present study provides a slightly more complex picture than the findings reported in prior literature.

\section{Managerial implications}

Based on our study, it seems clear that managers of SMEs in high-tech industries striving to increase their innovation performance should consider a more open approach to innovation. As technology scouting is fairly easy to implement and also has strong positive effects on innovation performance, it seems appropriate to start with this activity. Doing so, the SME probably can reap significant benefits for a rather limited cost, and technology scouting also seems to be a good start regardless of the innovation ambitions in the firm.

The next step toward adoption of open innovation largely depends on whether incremental or radical innovation is the main focus of the firm. If the focal SME is inclined toward new-to-theindustry types of innovation (incremental innovation), which usually involves lower levels of investment, then our results indicate that much can be gained by collaborating with partners outside the value chain. Such horizontal technology collaboration with other firms can be beneficial for sharing development costs and sharing information. However, due to the risks associated with it, as noted by Christensen, Olesen, and Kjær (2005), it may be worthwhile to initiate collaboration with smaller firms rather than larger firms during the initial stages of innovation development.

If radical innovation is targeted by SME managers, then it will be advisable to team up with strong customer firms in the value chain and become a specialized supplier for them in the area where the firm has its competence base. An alternative is to set up and organize interactions with end users and lead users that can provide insights about future market needs. Technology sourcing is also a viable alternative to achieve radical innovation. Acquiring licenses or other forms of technology, or tapping into university knowledge that can help the company to commercialize new-to-the-world products (including services) or processes can provide a relatively safe shortcut to radical innovation (Chesbrough, Vanhaverbeke, and West 2006; Mohnen and Hoareau 2003). Thus, we would like to encourage SME managers to open their innovation process to more fully capture the value from technology, and to utilize the four suggested inbound open innovation activities to drive radical or incremental innovation performance, respectively.

\section{Limitations and Outlook}

This study has made an effort at contributing to the literature in technology and innovation management, and small business management by advancing our knowledge regarding effects of open innovation activities in the context of SMEs. Although our study has attempted to fill this gap, it has several limitations. First, the focus of this study has been solely on inbound open innovation activities. We understand that this repre- 
sents an incomplete view on open innovation as the dimensions of outbound activities were not included. The study by Van De Vrande et al. (2009), for example, highlights venturing or spinoffs, outward IP licensing, and employee involvement as three key outbound activities. Second, we have focused on a sample of Swedish high technologybased SMEs. This limits generalizability outside this context. However, doing so has provided us with the possibility to reduce uncontrolled noise in our sample, and future studies could benefit from building on our findings and testing the stated hypothesis in a larger sample from multiple industries and countries. Moreover, we have only examined the effects of open innovation activities, but the antecedents to these are still unexplored. We can also expect that the relationship between open innovation actives and innovative performance can be moderated by certain variables, such as technology strategy or external environment conditions. Finally, there may be interaction effects. Although not specifically focused in the present study, there is a probability that the proposed open innovation activities may substitute or compliment the effects on innovation performance dimensions of radical innovation and incremental innovation. Thus, future studies can explore the suggested research directions and build on the limited body of knowledge on open innovation and SMEs.

Another limitation is the reliance on perceptual measures and possible problems with common method variance, and we thus encourage future studies with objective measures, especially concerning the dependent variables. Altogether, we find that the role and effects of open innovation activities in the context of SMEs is an underresearched topic that needs further attention from researchers in technology and innovation management, and we hope that our study has provided an initial step toward understanding the complexities around this relationship.

\section{References}

Anokhin, S., J. Wincent, and J. Frishammar (2011). "A Conceptual Framework for Misfit Technology Commercialization," Technological Forecasting and Social Change 78(6), 1060-1071.

Argote, L., and P. Ingram (2000). "Knowledge Transfer: A Basis for Competitive Advantage in Firms," Organizational Behavior and Human Decision Processes 82(1), 150-169.

Atuahene-Gima, K. (1992). "Inward Technology Licensing as an Alternative to Internal R\&D in New Product Development: A Conceptual Framework," Journal of Product Innovation Management 9(2), 156-167.

(1993). "Buying Technology for Product Development in Smaller Firms," Industrial Marketing Management 22(3), 223-232.

(2005). "Resolving the Capability: Rigidity Paradox in New Product Innovation," Journal of Marketing 69(4), 61-83.

Baruch, Y. (1999). "Response Rate in Academic Studies-A Comparative Analysis," Human Relations 52(4), 421-438.

Baruch, Y., and B. C. Holtom (2008). "Survey Response Rate Levels and Trends in Organizational Research," Human Relations 61(8), 1139-1160.

Baum, J. A. C., T. Calabrese, and B. S. Silverman (2000). "Don't Go It Alone: Alliance Network Composition and Startups' Performance in Canadian Biotechnology," Strategic Management Journal 21(3), 267-294.

Belderbos, R., M. Carree, and B. Lokshin (2004). "Cooperative R\&D and Firm Performance," Research Policy 33(10), 1477-1492.

Bessant, J., R. Kaplinsky, and R. Lamming (2003). "Putting Supply Chain Learning into Practice," Inter- 
national Journal of Operations and Production Management 23(2), 167184.

Bianchi, M., S. C. Orto, F. Frattini, and P. Vercesi (2010). "Enabling Open Innovation in Small- and Medium-Sized Enterprises: How to Find Alternative Applications for Your Technologies," $R$ and D Management 40(4), 414-430.

Bradley, F., R. Meyer, and Y. Gao (2006). "Use of Supplier-Customer Relationships by SMEs to Enter Foreign Markets," Industrial Marketing Management 35(6), 652-665.

Burt, R. S. (2004). "Structural Holes and Good Ideas," The American Journal of Sociology 110(2), 349-399.

Chaney, P. K., T. M. Devinney, and R. S. Winer (1991). "The Impact of New Product Introductions on the Market Value of Firms," Journal of Business 64(4), 573-610.

Chesbrough, H. (2003). Open Innovation: The New Imperative for Creating and Profiting from Technology. Boston, MA: Harvard Business School Publishing Corporation.

Chesbrough, H., and A. K. Crowther (2006). "Beyond High Tech: Early Adopters of Open Innovation in Other Industries," $R$ and $D$ Management 36(3), 229-236.

Chesbrough, H., W. Vanhaverbeke, and J. West, Eds. (2006). Open Innovation: Researching a New Paradigm. New York: Oxford University Press.

Christensen, C. M., and J. L. Bower (1996). "Customer Power, Strategic Investment, and the Failure of Leading Firms," Strategic Management Journal 17(3), 197-218.

Christensen, J. F., M. H. Olesen, and J. S. Kjær (2005). "The Industrial Dynamics of Open Innovation: Evidence from the Transformation of Consumer Electronics," Research Policy 34(10), 1553-1549.

Cohen, W. M., and D. A. Levinthal (1990). "Absorptive Capacity: A New Perspective on Learning and In- novation," Administrative Science Quarterly 35(1), 128-152.

Cooper, R. G., S. J. Edgett, and E. J. Kleinschmidt (2003). Best Practices in Product Innovation: What Distinguishes Top Performers. Ancaster, ON: Product Development Institute.

Dahan, E., and J. R. Hauser (2002). "The Virtual Customer," Journal of Product Innovation Management 19(5), 332353.

De Toni, A., and G. Nassimbeni (2003). "Small and Medium District Enterprises and the New Product Development Challenge," International Journal of Operations and Production Management 23(6), 678697.

Dewar, R. D., and J. E. Dutton (1986). "The Adoption of Radical and Incremental Innovations: An Empirical Analysis," Management Science 32(11), 1422-1433.

Dyer, J. H., and H. Singh (1998). "The Relational View: Cooperative Strategy and Sources of Interorganizational Competitive Advantage," The Academy of Management Review 23(4), 660-679.

Enkel, E., C. Kausch, and O. Gassmann (2005). "Managing the Risk of Customer Integration," European Management Journal 23(2), 203-213.

Enkel, E., J. Perez-Freije, and O. Gassmann (2005). "Minimizing Market Risks Through Customer Integration in New Product Development: Learning from Bad Practice," Creativity and Innovation Management 14(4), 425437.

Ettlie, J. E., W. P. Bridges, and R. D. O'Keefe (1984). "Organization Strategy and Structural Differences for Radical versus Incremental Innovation," Management Science 30(6), 682-695.

Faems, D., B. Van Looy, and K. Debackere (2005). "Interorganizational Collaboration and Innovation: Toward a Portfolio Approach," 
Journal of Product Innovation Management 22(3), 238-250.

Fontana, R., A. Geuna, and M. Matt (2006). "Factors Affecting UniversityIndustry R\&D Projects: The Importance of Searching, Screening and Signaling," Research Policy 35(2), 309-323.

Freel, M. S. (1999). "Where Are the Skills Gaps in Innovative Small Firms?" International Journal of Entrepreneurial Behaviour and Research 5(3), 144-154.

Frishammar, J., and S. Andersson (2009). "The Overestimated Role of Strategic Orientations for International Performance in Smaller Firms," Journal of International Entrepreneurship 7(1), 57-77.

Frishammar, J., and A. S. Hörte (2005). "Managing External Information in Manufacturing Firms: The Impact on Innovation Performance," Journal of Product Innovation Management 22(3), 251-266.

Frishammar, J., U. Lichtenthaler, and J. Rundquist (2011). "Identifying Technology Commercialization Opportunities: The Importance of Integrating Product Development Knowledge," Journal of Product Innovation Management (in press).

Gans, J. S., and S. Stern (2003). "The Product Market and the Market for 'Ideas': Commercialization Strategies for Technology Entrepreneurs," Research Policy 32(2), 333-350.

Gassmann, O. (2006). "Opening Up the Innovation Process: Towards an Agenda," $R$ and D Management 36(3), 22-228.

Gemünden, H. G., P. Heydebreck, and R. Herden (1992). "Technological Interweavement: A Means of Achieving Innovation Success," $R$ and D Management 22(4), 359376.

Giarratana, M. S. (2004). "The Birth of a New Industry: Entry by Start-Ups and the Drivers of Firm Growth: The Case of Encryption Software," Research Policy 33(5), 787-806.

Grando, A., and V. Belvedere (2006). "District's Manufacturing Performances: A Comparison among Large, Small-to-Medium-Sized and District Enterprises," International Journal of Production Economics 104(1), 8599.

Griffiths-Hemans, J., and R. Grover (2006). "Setting the Stage for Creative New Products: Investigating the Idea Fruition Process," Journal of the Academy of Marketing Science 34(1), 27-39.

Grönlund, J., D. Rönnberg-Sjödin, and J. Frishammar (2010). "Open Innovation and the Stage-Gate Process: A Revised Model for New Product Development," California Management Review 52(3), 106-131.

Gruner, K. E., and C. Homburg (2000). "Does Customer Interaction Enhance New Product Success?," Journal of Business Research 49(1), 1-14.

Hagedoorn, J., N. Roijakkersand, and H. Van Kranenburg (2006). "Inter-Firm R\&D Networks: The Importance of Strategic Network Capabilities for High-Tech Partnership Formation," British Journal of Management 17(1), 39-53.

Hair, J. F., W. C. Black, B. J. Babin, R. E. Anderson, and R. L. Tatham (2006). Multivariate Data Analysis. Upper Saddle River, NJ: Pearson Prentice Hall.

Håkansson, H., and J. Laage-Hellman (1984). "Developing a Network R\&D Strategy," Journal of Product Innovation Management 1(4), 224-237.

Hamel, G., and C. K. Prahalad (1994). "Competing for the Future," Harvard Business Review 72(4), 122-128.

Henkel, J. (2006). "Selective Revealing in Open Innovation Processes: The Case of Embedded Linux," Research Policy 35(7), 953-969.

Huergo, E., and J. Jaumandreu (2004).

"How Does Probability of Innovation 
Change with Firm Age?," Small Business Economics 22(3-4), 193207.

Jarillo, J. C. (1989). "Entrepreneurship and Growth: The Strategic Use of External Resources," Journal of Business Venturing 4(2), 133-147.

Katila, R. (2002). "New Product Search over Time: Past Ideas in Their Prime?" The Academy of Management Journal 45(5), 995-1010.

Katila, R., and G. Ahuja (2002). "Something Old, Something New: A Longitudinal Study of Search Behavior and New Product Introduction," The Academy of Management Journal 45(6), 1183-1194.

Katz, R., and T. J. Allen (1982). Investigating the Not Invented Here (NIH) Syndrome: A Look at the Performance, Tenure, and Communication Patterns of 50 R \& D Project Groups," $R$ and D Management 12(1), 7-20.

Kim, P., and H. Aldrich (2005). Social Capital and Entrepreneurship. Delft, The Netherlands: Publishers Inc.

Kleinknecht, A., and J. O. N. Reijnen (1992). "Why Do Firms Cooperate on R\&D? An Empirical Study," Research Policy 21(4), 347-360.

Kogut, B. (2000). "The Network as Knowledge: Generative Rules and the Emergence of Structure," Strategic Management Journal 21(3), 405425.

Koput, K. W. (1997). "A Chaotic Model of Innovative Search: Some Answers, Many Questions," Organization Science 8(5), 528-542.

Koufteros, X., M. Vonderembse, and J. Jayaram (2005). "Internal and External Integration for Product Development: The Contingency, Effects of Uncertainty, Equivocality, and Platform Strategy," Decision Science 36(1), 97-133.

Lane, P. J., B. R. Koka, and S. Pathak (2006). "The Reification of Absorptive Capacity: A Critical Review and Rejuvenation of the Construct," The
Academy of Management Review 31(4), 833-863.

Laursen, K., and A. Salter (2006). "Open for Innovation: The Role of Openness in Explaining Innovation Performance among U.K. Manufacturing Firms," Strategic Management Journal 27(2), 131-150.

Lecocq, X., and B. Demil (2006). "Strategizing Industry Structure: The Case of Open Systems in a Low-Tech Industry," Strategic Management Journal 27(9), 891-898.

Lee, S., G. Park, B. Yoon, and J. Park (2010). "Open Innovation in SMEs-An Intermediated Network Model," Research Policy 39(2), 290300.

Lichtenthaler, E. (2003). "Third Generation Management of Technology Intelligence Processes," $R$ and $D$ Management 33(4), 361-375.

(2007). "Managing Technology Intelligence Processes in Situations of Radical Technological Change," Technological Forecasting and Social Change 74(8), 1109-1136.

Lichtenthaler, U. (2005). "External Commercialization of Knowledge: Review and Research Agenda," International Journal of Management Reviews 7(4), 231-255.

— (2008a). "Open Innovation in Practice: An Analysis of Strategic Approaches to Technology Transactions," IEEE Transaction 55(1), 148157.

(2008b). "Opening Up Strategic Technology Planning: Extended Roadmaps and Functional Markets," Management Decision 46(1), 77-91.

(2010). "Open Innovation: Potential Risks and Managerial Countermeasures," paper presented at the R\&D Management Conference, Manchester, Great Britain, June.

(2011). "Open Innovation: Past Research, Current Debates, and Future Directions," Academy of Management Perspectives 25(1), 75-93. 
Lichtenthaler, U., and H. Ernst (2007). "Developing Reputation to Overcome the Imperfections in the Markets for Knowledge," Research Policy 36(1), 37-55.

Lichtenthaler, U., and E. Lichtenthaler (2010). "A Capability-Based Framework for Open Innovation: Complementing Absorptive Capacity," Journal of Management Studies 46(3), 1315-1337.

Lichtenthaler, U., E. Lichtenthaler, and J. Frishammar (2009). "Technology Commercialization Intelligence: Organizational Antecedents and Performance Consequences," Technological Forecasting and Social Change 76(3), 301-315.

Liebeskind, J. P., A. L. Oliver, L. Zucker, and M. Brewer (1996). "Social Networks, Learning, and Flexibility: Sourcing Scientific Knowledge in New Biotechnology Firms," Organization Science 7(4), 428-443.

Madrid-Guijarro, A., D. Garcia, and $\mathrm{H}$. Van Auken (2009). "Barriers to Innovation among Spanish Manufacturing SMEs," Journal of Small Business Management 47(4), 465-488.

Miller, D. H., and P. H. Friesen (1982). "Innovation in Conservative and Entrepreneurial Firms: Two Models for Strategic Momentum," Strategic Management Journal 3(1), 125.

Miotti, L., and F. Sachwald (2003). "CoOperative R\&D: Why and with Whom?: An Integrated Framework of Analysis," Research Policy 32(8), 1481-1499.

Mohnen, P., and C. Hoareau (2003). "What Type of Enterprise Forges Close Links with Universities and Government Labs? Evidence from CIS 2," Managerial and Decision Economics 24(2-3), 133-145.

Oliver, A. L. (2001). "Strategic Alliances and the Learning Life-Cycle of Biotechnology Firms," Organization Studies 22(3), 467-489.
Pavitt, K. (1998). "Technologies, Products and Organization in the Innovating Firm: What Adam Smith Tells Us and Joseph Schumpeter Doesn't," Industrial and Corporate Change 7(3), 433-452.

Pittaway, L., M. Robertson, K. Munir, D. Denyer, and A. Neely (2004). "Networking and Innovation: A Systematic Review of the Evidence," International Journal of Management Reviews 5-6(3-4), 137-168.

Podsakoff, P. M., S. B. MacKenzie, J. Y. Lee, and N. P. Podsakoff (2003). "Common Method Biases in Behavioral Research: A Critical Review of the Literature and Recommended Remedies," Journal of Applied Psychology 88(5), 879-903.

Podsakoff, P. M., and D. W. Organ (1986). "Self-Reports in Organizational Research: Problems and Prospects," Journal of Management 12(4), 531-544.

Powell, W. W., K. W. Koput, and L. Smith-Doerr (1996). "Interorganizational Collaboration and the Locus of Innovation: Networks of Learning in Biotechnology," Administrative Science Quarterly 41(1), 116-145.

Ragatz, G. L., R. B. Handfield, and K. J. Petersen (2002). "Benefits Associated with Supplier Integration into New Product Development under Conditions of Technology Uncertainty," Journal of Business Research 55(5), 389-400.

Ragatz, G. L., R. B. Handfield, and T. V. Scannell (1997). "Success Factors for Integrating Suppliers into New Product Development," Journal of Product Innovation Management 14(3), 190-202.

Rothwell, R., and M. Dodgson (1991). "External Linkages and Innovation in Small and Medium-Sized Enterprises," $R$ and D Management 21(2), 125-138. Sher, P. J., and P. Y. Yang (2005). "The Effects of Innovative Capabilities and R\&D Clustering on Firm Performance: 
The Evidence of Taiwan's Semiconductor Industry," Technovation 25(1), 33-43.

Stam, W., and T. Elfring (2008). "Entrepreneurial Orientation and New Venture Performance: The Moderating Role of Intra- and Extraindustry Social Capital," Academy of Management Journal 51(1), 97-111.

Tao, J., and V. Magnotta (2006). "How Air Products and Chemicals 'Identifies and Accelerates'," Research Technology Management 49(5), 12-18.

Teece, D. J. (1989). "Inter-Organizational Requirements of the Innovation Process," Managerial and Decision Economics 10(Special Issue), 35-42.

Van De Vrande, V., J. P. J. De Jong, W. Vanhaverbeke, and M. De Rochemont (2009). "Open Innovation in SMEs: Trends, Motives and Management Challenges," Technovation 29(6-7), 423-437.

Van Wyk, R. J. (1997). "Strategic Technology Scanning," Technological Forecasting and Social Change 55(1), 21-38.

Vanhaverbeke, W., G. Duysters, and N. Noorderhaven (2002). "External Technology Sourcing through Alliances or Acquisitions: An Analysis of the Application-Specific Integrated Circuits Industry," Organization Science 13(6), 714-733.
Veryzer, R. W. (1998). "Discontinuous Innovation and the New Product Development Process," Journal of Product Innovation Management 15(4), 304-321.

- (2005). Democratizing Innovation. Cambridge, MA: MIT Press.

Von Hippel, E., and R. Katz (2002). "Shifting Innovation to Users via Toolkits," Management Science 48(7), 821-833.

Vossen, R. W. (1998). "Research NoteRelative Strengths and Weakness of Small Firms in Innovation," International Small Business Journal 16(3), 88-94.

Westerberg, M., J. Singh, and E. Häckner (1997). "Does the CEO Matter? An Empirical Study of Small Swedish Firms Operating in Turbulent Environments," Scandinavian Journal of Management 13(3), 251-270.

Xin, J., A. Yeung, and T. Cheng (2008). "Radical Innovations in New Product Development and Their Financial Performance Implications: An Event Study of US Manufacturing Firms," Operations Management Research 1(2), 119-128.

Zahra, S. A., and G. George (2002). "Absorptive Capacity: A Review, Reconceptualization, and Extension," Academy of Management Review 27(2), 185-203. 


\begin{tabular}{|c|c|c|c|c|c|}
\hline \multirow[t]{2}{*}{ Construct } & \multirow[t]{2}{*}{ Items } & \multicolumn{4}{|c|}{ Factor Loading } \\
\hline & & $\mathbf{1}$ & 2 & 3 & 4 \\
\hline Technology Scouting 1 & Observe technology trends & & 0.893 & & \\
\hline Technology Scouting 2 & $\begin{array}{l}\text { View external sources for ideas, knowledge } \\
\text { as important }\end{array}$ & & 0.903 & & \\
\hline Technology Scouting 3 & Collect deep information about our industry & & 0.710 & & \\
\hline Technology Sourcing 1 & $\begin{array}{l}\text { Regularly contact R\&D institutes and } \\
\text { universities to access new technology }\end{array}$ & & & 0.867 & \\
\hline Technology Sourcing 2 & $\begin{array}{l}\text { Often buy and use new technology (IPRs) } \\
\text { from other firms and institutions }\end{array}$ & & & 0.823 & \\
\hline $\begin{array}{l}\text { Horizontal Technology } \\
\text { Collaboration } 1\end{array}$ & $\begin{array}{l}\text { Cooperate and co-develop with other firms } \\
\text { (e.g., competitors and/or non-competitors) }\end{array}$ & 0.745 & & & \\
\hline $\begin{array}{l}\text { Horizontal Technology } \\
\text { Collaboration } 2\end{array}$ & $\begin{array}{l}\text { Regularly network to exchange experiences/ } \\
\text { knowledge with partners }\end{array}$ & 0.858 & & & \\
\hline $\begin{array}{l}\text { Horizontal Technology } \\
\text { Collaboration } 3\end{array}$ & $\begin{array}{l}\text { Our network partners contribute with } \\
\text { important input }\end{array}$ & 0.886 & & & \\
\hline $\begin{array}{l}\text { Vertical Technology } \\
\text { Collaboration } 1\end{array}$ & Involve present customers & & & & 0.796 \\
\hline $\begin{array}{l}\text { Vertical Technology } \\
\text { Collaboration } 2\end{array}$ & Involve future potential customers & & & & 0.696 \\
\hline $\begin{array}{l}\text { Vertical Technology } \\
\text { Collaboration } 3\end{array}$ & Involve end-users & & & & 0.937 \\
\hline
\end{tabular}

